\title{
Obituaries
}

Obituaries should be submitted by email to Laura Pacey at I.pacey@nature.com.

All submitted obituaries should be 350 words maximum in length (apart from obituaries for past presidents of the BDA where the length should be $700-800$ words).

Content of the obituary is down to the individual author, and the approval of the family should be given for the obituary prior

to submission to the $B D J$.

\section{GORDON JAMES TUCKER}

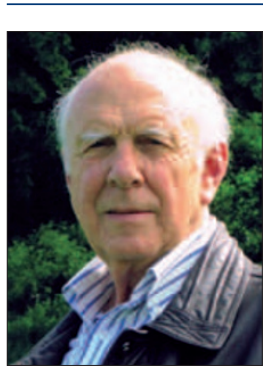

Gordon Tucker died suddenly at his home in Bristol on Thursday 22 March 2012, at the age of 81 . In 1957 Gordon graduated from Bristol University (BDS) and after a period spent in general practice and Peter Blyth's orthodontic practice, he joined Bristol's School Dental Service in 1966. In 1974 this became the NHS Community Dental Service and Gordon was appointed Assistant District Dental Officer responsible for its day-to-day management, as well as taking on the role of clinical teacher in the Department of Child Dental Health.

Gordon treated patients of the Community Dental Service until his retirement in 1994 and was the consummate professional. He was a great supporter both of the British Society of Paediatric Dentistry and of the British Dental Association. For the BDA, he held a variety of positions both in its Bristol and District Section and the Western Counties Branch, including a period of seven years as Branch secretary and a year as its president, followed by three years as chairman of its council. He was also active in the CDS Group of the BDA, including a year's term as national president.

Outside of dentistry, Gordon lived life to the full. Widely-travelled and an inveterate walker, he had a keen eye for the places in which he found himself. His interest in architecture and the built environment manifested itself in his long and active membership of Bristol
Civic Society, for which he served as secretary for a lengthy period; enjoyed a period of office as its chairman and was the long-term organiser of the group of its members that, on behalf of the Society, scrutinises and comments on planning applications registered in the city.

A very cultured man, Gordon was a committed supporter of the arts, particularly of the theatre and cinema, and had a deep love of music, regularly attending concert recitals. His interest in the graphic arts inspired a fine collection of artwork and sculpture. He was also something of a bon vivant, with a lively appreciation of good food, wines and beers and a fine dress sense, particularly manifested in his splendid choice of ties.

Most of all, he was a man who, having chosen his friends wisely, cherished their friendship. They will be glad that he kept his faculties and vigour to the end. Though they will miss him they will certainly not forget him.

Glyn Duggan

\section{PAUL LAMB WILKINSON}

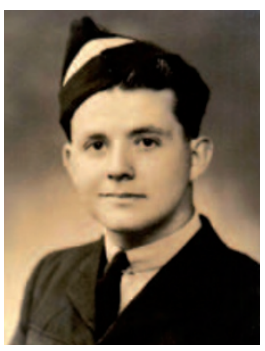

Paul was born in Campsie, NSW in 1923 on 4 February. At 16-years-old he left school and became a clerk in the Commonwealth Bank of Australia. He enlisted in

the RAAF in 1942. After training as a navigator in Canada he was posted to 463 Squadron, RAF Waddington. His crew became operational in August 1944 and completed 37 operations at a time when the fatality rate amongst aircrew was $45 \%$. On one occasion his Lancaster limped home on two of its four engines.
On demobilisation, unable to afford to study medicine for six years, he studied dental surgery. During the course he met Vena (Lavinia). They were married in 1950 and travelled to England the following year.

Paul first practiced in Ladbroke Road before settling in Notting Hill Gate. At the time Notting Hill was bedsit land, full of aspiring actors. As their careers flourished, so did his practice. Watching television in the 1970s was like looking through his appointment book.

After his children had left home, his practice moved firstly to 22 Harley Street and then to Cavendish Square. With great sadness he gave up practising aged 75. He said that when he went to a squadron reunion, he was the only one still working and his patients' names were as likely to appear in the obituary pages as in his appointment book.

Throughout his life he enjoyed various pursuits, taking chemistry and French at evening school and reading all the French classics with his dictionary to hand. He had learnt to sail in the 1950s and competed in several ocean races, earning membership of the Royal Ocean Racing Club. He remained a keen squash player into his sixties, having learnt to play in the air force. He had a great love of the garden, propagating geraniums, fuchsias, petunias and roses as well as managing a productive kitchen garden.

He was first and foremost a family man. His beloved wife, Vena, predeceased him just after their 62nd anniversary, and after temporarily rallying, he died peacefully on 5 December 2012.

He leaves three children (one an orthopaedic surgeon), nine grandchildren and three great-grandchildren.

Mike Wilkinson 